\title{
Child's Sundanese Story Dictation: A Case Study of A 5-Year-Old Indonesian Child
}

\author{
Mika Agesti ${ }^{1}$, Winti Ananthia ${ }^{2}$, Desiani N. Muliasari ${ }^{3}$, Charlotte Ambat Harun ${ }^{4}$, Endah Silawati \\ 13,5PG-PAUD Universitas Pendidikan Indonesia \\ 2,4PG-PAUD Universitas Pendidikan Indonesia
}

\section{ABSTRACT}

This paper is a part of a bigger research about the implementation of story project that attempts to develop children's critical literacy skill. The discussion in this paper focuses at the implementation of Sundanese story dictation on a 5-year-old child. The present study aims to identify the process of the story dictation, which is conducted for the very first time as a method to help children in expressing their own-created stories. Case study was employed as the research method. The subject of the present study was a 5-year-old boy who speaks Sundanese fluently and can express his ideas orally, in an kindergarten in Kabupaten Bandung. Story dictation was the method used to enable the subject to create a Sundanese story. The data were collected through videotapped observation, in-depth interview and teacher's field notes during the process of story dictation. Subsequently, the collected data were analysed. The finding revealed that the subject was able to complete the process of the story dictation voluntarily and could express his own story fluently. The investigation has shown that the created story can be categorised as a very good one.

\section{KEY WORDS}

case study research, early childhood education, story dictation, Sundanese story

CORRESPONDING AUTHOR:

email: agestimika@gmail.com

Manuscript submitted June 28, 2018; accepted Agustus 18, 2018.
Copyright: (C2018 This is an open access article under the terms of the Creative Commons Attribution License, which permits unrestricted use, distribution, and reproduction in any medium, provided the original author and source are credited.

\section{INTRODUCTION}

The paper is written as a part of a bigger study that investigates the implementation of story dictation to develop children's critical literacy skills. In the process of the research, a unique phenomenon was recognized in which the researchers decided to highlight it in a more focused discussion. One of the participants of the study shows better storytelling ability than his peers. He is able to express his story in Sundanese (his mother tongue), fluently. The researchers considered that this phenomenon should be discussed in addition to the discussion about the most appropriate technique for the story dictation (Ananthia, Harun, Muliasari \& Silawati, 2017). It is, however, related to the characteristic of the qualitative research that the research can lead to and result to other things despite of the determined research questions (Merriam, 2002).

Preserving Mother Tongue through Children 
Sundanese is a language spoken by approximately 34 million people native to Pasundan, West Java (Kurniawan, 2013). Despite of its function as the principal mode of communication and a local content subject, most of young people living in urban areas prefer using Bahasa Indonesia due to its function as primary language, especially in formal occasions. Hence, in big cities, e.g., Bandung, Sundanese is commonly used in the family circle and on casual meetings. Such situation is an example of the phenomenon of children in many countries whose primary language differs from the language of instruction in school (Ball, 2011).

The enthusiasm to show ethnic pride has resulted to some efforts made by local government in supporting the revitalization of Sundanese language. One of the efforts is by organising a day in a week in which Sundanese will be used as primary language in all settings, including offices and schools (Kurniawan, 2013). To support the program, the researchers suggest the method of story dictation as an activity in kindergartens to implement Sundanese language program as suggested by the government. By varying language-related activities, it is expected that children whose primary language is not the language of instruction in school can improve their native language fluency and literacy. Moreover, it is presumed that children's fluency and literacy in their mother tongue relates to the cognitive and linguistics foundation for learning other languages (Ball, 2011). Likewise, Benson (1004) confirmed that children learn best in their mother tongue.
The inclusion of Sundanese in the school program as the revitalization of local language allows children to have communication and interaction with peers and teachers in their mother tongue on increasingly various topics beyond household matters. Therefore, the program can be considered as an endeavour to preserve mother tongue (Ball, 2011).

\section{Critical Literacy}

Critical thinking is one of the important skills needed in the $21^{\text {st }}$ century to establish a society with decent ability of communication, ICT, citizenship and collaboration (Trilling \& Fadel, 2009). Literacy development is aspired to enhance children's critical literacy and later, the development of children's critical thinking (Wray, 2013). Critical literacy is not merely reading the words of a text, but also understanding the socio-cultural context of the text (McLaughlin \& DeVoogd, 2004) and conscious experience constructed within specific power relations (Fajardo, 2015). Critical literacy skill can be developed since the early years (Roche, 2015). Therefore, it is recommended for early childhood education practitioners to promote activities linked to literacy development, particularly in new condition (Luke \& Freebody, 1999). It is also suggested for teachers and researchers to know the variety of instructional activities in promoting children's critical literacy that suits best to a particular context (Jones, 2012). In improving children's critical literacy skills, story can be an effective form (Roche, 2015; Jones, 2012). Jones (2012) suggested that story can develop children's familiarity to text that offers them the opportunities to practically decode new words and their 
meanings within a predictable storyline and context.

\section{Story and Storytelling}

The employment of stories in a classroom could be used to open up space for building children's awareness of critical literacy (Leland, Harste \& Huber, 2005). In addition, story is one of the most suitable media for children (Damayanti, 2007; Brewster, Ellis \& Girard, 2002; Isbell, Sobol, Lindauer \& Lowrance, 2004; Collins, 1999) in developing their critical literacy (Roche, 2015; Stribling, 2014; Vasquez, 2014).

The presence of stories among the children can introduce a myriad of situations from the most familiar to the most unknowledgeable ones. Thus, stories can address children to take position or point of view while imagining if they experience similar situations (Kuyvenhoven, 2009; Davies, 2007; Gadzikowski, 2007; Haven, 2000).

However, although story and storytelling is a familiar thing in Indonesia, particularly at early childhood stage, most teachers have insufficient self-confidence in delivering a story in the classroom (Ananthia, 2010; Harun \& Ananthia, 2013). Moreover, they have less experience in connecting storytelling activity with the attempts of enhancing children's critical literacy.

Furthermore, teachers can discuss the book to develop the critical ability of readers/students (Jones, 2012; Roche, 2015). Moreover, several questions can also be posed to accomplish a particular project in order to enhance students' critical literacy skills.
Unfortunately, the employment of story in the classroom is still limited on how teachers present the stories through storytelling and story-reading (Groce, 2004), especially in the context of Indonesian early childhood education (Ananthia, 2010; Harun \& Ananthia, 2013; Yuliariatiningsih, Ananthia \& Yanthi, 2013). Meanwhile, literacy and critical thinking refers to problem-solving ability (Stribling, 2014; Wray, 2013) and is recommended for learners in order to develop their ability to create something (Wray, 2013). In developing children's ability to create something, they can be asked to invent their own stories that are wrapped in the employment of story dictation as one of the forms of Project-Based Learning (PBL).

\section{Project-Based learning}

In the bigger scope of the study, the researchers try to involve children in the effort to develop their critical literacy by requiring them to accomplish a particular project: to create their own story. Similar to other researches on PBL that highlight the process and the product (Comber, Thomson \& Wells, 2001; Mikulec \& Miller, 2011; Lotherington, Holland, Sotoudeh \& Zentena, 2008; Dooly \& Sadler, 2016), the present study uses PBL to expose children in solving problems within the process of creating the product, namely their own stories.

Furthermore, the project gives the children opportunities to acquire literacy practices that combine production, design, and communication in a variety of modes through a range of media (Comber et al., 2001). In the present study, children are assisted by teachers to become part of the material and 
discursive practices. By creating their own story as the product of the project, it is expected that they can develop their critical literacy skills.

\section{Story Dictation}

Most of studies on the implementation of PBL discuss children's writing as a key element in developing critical literacy skills and as the practices that mediate their emotions, intellectual and academic learning, social practice, and political activism (Comber et al., 2001). Since most of PBL products require children's writing skill (Comber et al., 2001; Mikulec \& Miller, 2011; Lotherington et al., 2008; Dooly \& Sadler, 2016), children are also expected for having adequate reading skill. Thus, it seems difficult to implement PBL in kindergarten whose student's reading and writing skills are still limited.

Fortunately, Gadzikowski (2007) asserted the implementation of PBL on young children can be done through story dictation. Christ, Wang and Chiu (2011) and St, James Lutheran (2017) have conducted researches on how teacher could create opportunity for children to invent their own story through story dictation. Story dictation offers the opportunity for young children to create their own story as soon as they are able to speak in sentences despite their limited reading and writing skills (Gadzikowski, 2007). The present study attempts to describe the process of the story dictation carried out by a student in which the product of the PBL is also carefully examined.

\section{RESEARCH METHOD}

The research is conducted to investigate the process of kindergarten students in inventing their own story in the implementation of story dictation. However, this paper is only focused on a student as one of the participants of the study. Thus, this paper is a part of a larger study.

A 5-year-old participant of the study became the subject of the discussion of this paper since he showed a quite different characteristic among the children involved in the study. This study is a qualitative research since the researchers aim to understand and explain the participant's point of view of an issue or phenomenon (Creswell, 2009; Denzin \&Lincoln, 2000; Maxwell, 2005; Merriam, 1998, 2002). In the present study, it particularly reveals the process of story dictation experienced by the subject.

Since the study attempts to concentrate on and specifically describe a single phenomenon, case study is chosen as a type of qualitative research design (Stake, 1995; Creswell, 2009; McMillan \& Schumacher, 2010; Merriam, 1998, 2002, 2009; Yazan, 2015). Furthermore, by employing the case study, the researchers are able to explore an empirical inquiry into a phenomenon within its real-life context (Yin, 2003; Yazan, 2015), namely by investigating the experiences of the subject of this study outside the formal teaching and learning activities.

The research was conducted in a kindergarten in Kabupaten Bandung. The study investigated the implementation of Sundanese story dictation and was held for five days. During the study, the researchers found one of the participants, a 5-year-old 
boy, who has outstanding storytelling ability. He was also capable to be involved in a deeper study - which focus more on his ability in storytelling.

The data were collected from observation, in-depth nterview and teacher's field noted. Prior to the analysis, codification and categorization of the themes emerged during the process of the Sundanese story dictation done by the subject were conducted.

\section{RESULTS AND DISCUSSION}

There are six steps in the process of story dictation (Ananthia et al., 2017). Based on the six steps, the activities carried out by the subject were carefully examined. The first step was storytelling. The teacher told the story and the subject seemed to fully concentrate on the delivered story. It could be identified from his eye contact with the teacher. In addition, the subject stayed focus and was not distracted during the process of the storytelling.

The second step was introducing doodle pages. In this step, the subject was required to complete the doodle pages. During the activity, the subject showed his fluent Sundanese in interacting with peers and teacher, which was different from peers who mainly spoke Bahasa Indonesia (see Figure 1).
Subject : Burung teh manuk.

Bird is manuk.

(told one of his friend the Sundanese of 'bird').

Subject : Bunda ieu jadi anakna. Miss, this one is the child. (showed his picture to the teacher).

Teacher: ... Warnaan heula etana... Color the picture first.

The boy: Bunda ieu tos jadi acan? Miss, is it done? (gave his picture to the teacher).

Teacher: Ieu warnaan heula sadayana. You have to color all the pictures.

The boy : Sadayana ieu?

All the pictures?

(pointed to the pictures).

Figure 1. Excerpt from video transcript.

The third step was planning story extension. During the third step, the subject was given some time to create and plan the story extension based on the teacher's storytelling and the doodle pages. The subject discussed it with peers and the teacher. In the discussion, the subject did not involve too much and mostly agreed with the idea from his peers. Therefore, the researchers could not obtain more data about the subject's verbal performance.

The forth step was the story dictation, which was surprising the researchers. The step revealed the ability of the subject in having interactive and splendid utterances. The teacher did not have to push the subject to express his idea. The subject could easily create his own story. It can be seen from the length of his story. In this step, the subject narrated his own story while the teacher wrote every single word. Since the length of the story was longer compared to those created by other students, the teacher's 
handwriting of the story almost covered the subject's doodle page. In expressing his story, the subject often used assorted words that uncommonly used by 5 -year-old children. For example, the word "dulur" (relatives), "macokan" (to bite repeatedly), "ngadodoho" (stalking), and "ngabongohan" (to attack). By giving him opportunities to use mother tongue within the school, students will be used to involve a more complex communication beyond household matters as a foundation to develop their cognitive and linguistics abilities (Ball, 2011). As the result, school has engaged as an institution that participates in preserving mother tongue so that children can perform their best performance in the learning environment (Benson, 2004).

Having the story devised in the previous step, the fifth step was the process of the story revision. In this step, some activities were conducted. The doodle pages collected from all students as the participant were gathered into a single story book. The sequences of the pages were discussed by both students and teacher. The teacher guided the students to make the front- and back cover of the book. The front cover contains the title of the story and also some pictures related to the produced story book. The students discussed the title and agreed to title it with "Manuk Nyasar" (The Lost Bird). In making the front cover, they cooperatively wrote the title, drew and coloured the pictures. Meanwhile, for the back cover, the students wrote their names as the authors of the book. The teacher asked the children one by one to write down their name. The subject of the present study said that he could not write his own name. Therefore, the teacher helped him in writing his name on the back cover. It showed that despite of the subject's ability in creating his own story, he has limited ability in reading and writing. Thus, it is obvious that story dictation can assist children with limited writing skill to express their ability of storytelling into a written text (Gadzikowski, 2007).

The completion of the gathered doodle pages with front and back cover into a book was accompanied by evaluation and discussion that involved the students and the teacher. It determined whether the story should be revised or not. The revision evolved between the story line, the choice of the word and the sentence structure and grammar. Different from the step of story dictation that suggests the teacher for only writing what the subject narrates to the teacher, the revision highlights the importance of correcting the subject's work. In the present study, the subject created story and then made some revisions in the story line. He added more characters into the story hence the story was longer (see Figure 2). 


\section{ECRJ}

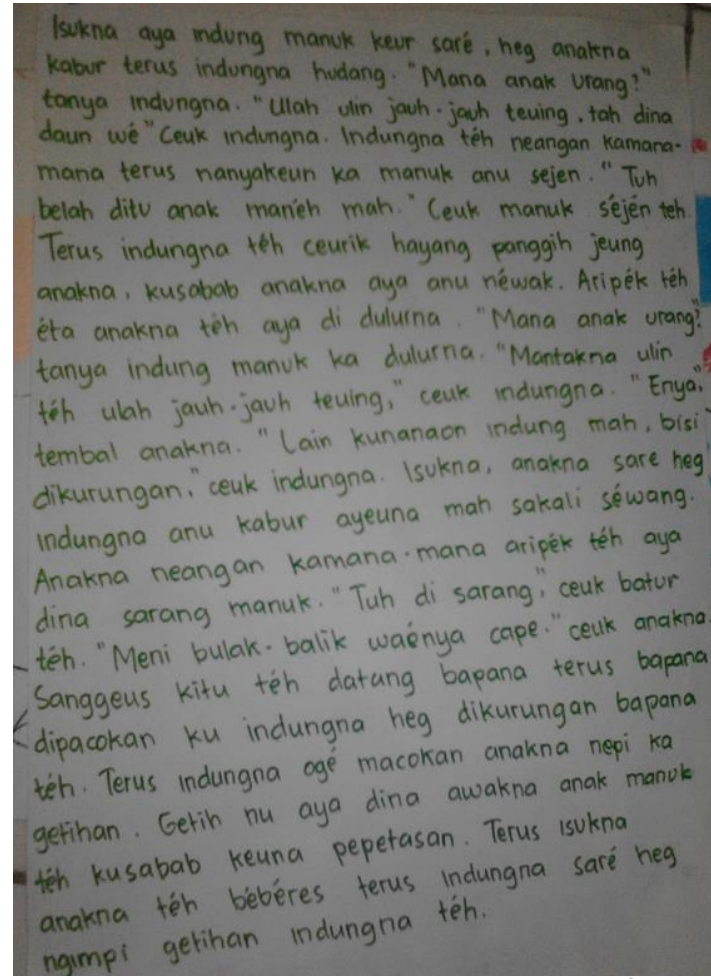

Figure 2. The draft of the story.

Finally, the last step was the publication of the story. In this step, it was conducted in the form of storytelling.

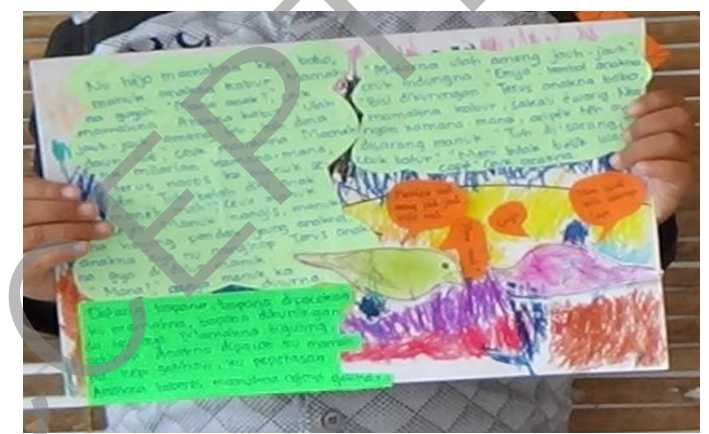

Figure 3. Publishing the story.

Unlike the storytelling in the first step, in the fifth step, the teacher delivered the storytelling using the story book which consisted of the children's doodle pages compilation. When the teacher started reading the subject's story, other students could directly recognise it from the length of the story that was handwritten by the teacher. Most of the children in the class agreed that the subject's story was exciting. In the created story, one of the characters in the story was hurt by a firecracker. The topic triggered further discussion among the children. The story extended into a discussion among them. They seemed to be attached to the subject's story and reflected it into their own experience. This situation revealed that the children explored the social acceptability and habits in their communities about playing firecrackers. They weaved interaction with peers in which they could testify their experiences within the presence of the story. The students discuss a story and show a sense of "weaving ourselves into We-ness" (Kuyvenhoven, 2009) when learning activities takes place in the presence of each other (Davies, 2007; Haven 2000).

\section{CONCLUSION}

A study has been done to investigate a 5year-old student who has fluency in expressing his ideas in his mother tongue. In the process of story dictation, the subject showed that he could produce not only high frequency level of words, but also rarely used Sundanese words. The implementation of Sundanese story dictation gave the subject an opportunity to use his mother tongue in a more complex context beyond household matters.

Based on the finding of the present study, it is suggested that school potentially play a role in preserving local wisdoms, including as 
mother tongue, to develop children's cognitive and linguistics ability. Therefore, school should facilitate the talent and interest of the students through selective activities.

\section{REFERENCES}

Ananthia, W. (2010). Storytelling in an Indonesian primary school EFL context: Teachers perspectives. (Unpublished master thesis). Monash University, Australia.

Ananthia, W., Harun, C. A., Muliasari, D. N., \& Silawati, E. (2017). Experiential learning of future teachers in story dictation for early childhood education. Proceeding on the Tenth International Conference on Applied Linguistics. Bandung, Indonesia.

Ball, J. (2011). Enhancing learning of children from diverse language background: Mother tongue-based bilingual or multilingual education in the early years. Commissioned for UNESCO. France: UNESCO.

Benson, C. (2004). The importance of mother tongue-based schooling for educational quality. Paper commissioned by the Education for all Global Monitoring Report 2005 the quality imperative. UNESCO.

Brewster, J., Ellis, G., \& Girard, D. (2002). The primary English teacher's guide. London: Penguin.

Collins, F. (1999). The use of traditional storytelling in education to the learning of literacy skills. Early Child Development and Care, 152(1), 77-108.

Comber, B., Thomson, P., \& Wells, M. (2001). Critical literacy finds a place: Writing and social action in a low-income Australian grade 2/3 classroom. The Elementary School Journal, 101(451-464), 453-457.

Creswell, J. W. (2009). Qualitative, quantitative, and mixed method approaches (3rd ed.). Thousand Oaks: Sage Publication, Inc.

Christ, T., Wang, X. C., \& Chiu, M. M. (2011). Using story dictation to support young children's vocabulary development: Outcomes and process. Early Childhood Research Quarterly, 26, 30-41.

Damayanti, I. L. (2007). Storytelling in language classroom for young learners: Practical use of homemade story and 'real' story. Englishiana: Journal of English Language Pedagogy, 3(1), 1-12.

Davies, A. (2007). Storytelling in the classroom: Enhancing traditional oral skills for teachers and pupils. London: Paul Chapman Publishing.

Denzin, N. K., \& Lincoln, Y. S. (2000). Introduction: The discipline and practice of qualitative research. In N. K. Denzin \& Y. S. Lincoln (Eds.), Handbook of qualitative research (2nd ed.). Thousand Oaks: Sage Publication, Inc.

Dooly, M., \& Sadler, R. (2016). Becoming little scientists: Technologically-enhanced project-based language learning. Language Learning \& Technology, 20(1), 54-78. Retrieved from http://It.msu/issues/february2016/doolys adler.pdf.

Fajardo, M. F. (2015). A review of critical literacy beliefs and practices of English language learners and teachers. University of Sydney Papers in TESOL, 10, 29-56.

Gadzikowski, A. (2007). Story dictation: A guide for early childhood professionals. St. Paul: Readleaf Press. 
Groce, R. D. (2004). An experiential study of elementary teachers with the storytelling process: Interdisciplinary benefits associated with teacher training and classroom integration. Reading Improvement, 41(2), 122-128.

Harun, C. A., \& Ananthia, W. (2013). Model self-training untuk meningkatkan keterampilan storytelling mahasiswa dalam pembelajaran bahasa Inggris SD. Unpublished Research Report. LPPM UPI, Bandung.

Haven, K. (2000). Super simple storytelling: a can-do guide for every classroom, every day. Colorado: Teacher Ideas Press.

Isbell, R., Sobol, J., Lindauer, L., \& Lowrance, A. (2004). The effects of storytelling and story reading on the oral language complexity and story comprehension of young children. Early Childhood Education Journal, 32(3), 157-163.

Jones, S. (2012). Critical Literacies in the making: Social class and identities in the early reading classroom. Journal of Early Childhood Literacy, 13(2), 197-224.

Kurniawan, E. (2013). $\begin{array}{r}\text { Sundanese } \\ \text { complementation. }\end{array}$
Unpublished dissertation. University of lowa. Retrieved from http://ir.uiowa.edu/etd/2554

Kuyvenhoven, J. (2009). In the presence of each other: A pedagogy of storytelling. Toronto: University of Toronto Press.

Leland, C. H., Harste, J. C., \& Huber, K. R. 2005. Out of the box: Critical literacy in a first-grade classroom. Language Arts, 82(5), 257-268.

Luke, A. \& Freebody, P. (1999). Further note on the four resources model: Reading online. Retrieved from http://www.readingonline.org/research/lu kefreebody.html

Lotherington, H., Holland, M., Sotoudeh, S., \& Zentena, M. (2008). Project-based community language learning: Three narratives of multilingual story-telling in early childhood education. The Canadian Modern Language Review, 65(1), 125-145.

Maxwell, J. A. (2005). Qualitative research design: An interactive approach (2nd Ed.). London: Sage Publication.

McLaughlin, M., \& DeVoogd, G. (2004). Critical literacy as comprehension: Expanding reader response. Journal of Adolescent and Adult Literacy, 48(1), 52-82.

McMillan, J. H., \& Schumacher, S. (2010). Research in education: Evidence-based inquiry (7th ed.). Upper Saddle River: Pearson Education, Inc.

Merriam, S. B. (1998). Qualitative research and case study applications in education: Revised and expanded from case study research in education. San Francisco: Jossey-Bass.

Merriam, S. B. (2002). Introduction to qualitative research. In S. B. Merriam (Ed.), Qualitative research in practice: Examples for discussion and analysis. San Francisco: Jossey-Bass.

Merriam, S. B. (2009). Qualitative research: $A$ guide to design and implementation. San Francisco: Jossey-Bass.

Mikulec, E., \& Miller, P. C. (2011). Using project-based instruction to meet foreign language standards. The Clearing House: $A$ Journal of Educational Strategies, Issues and Ideas, 84(3), 81-86.

Roche, M. (2015). Developing children's critical thinking through picturebooks. New York: Routledge. 


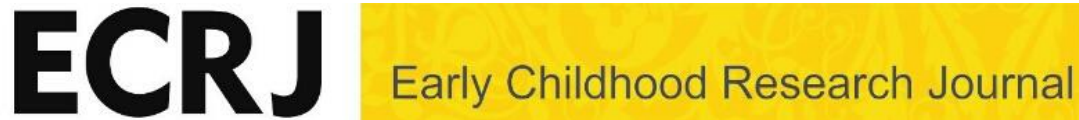

Stake, R. E. (1995). The art of case study research. Thousand Oaks: Sage Publications, Inc.

Stribling, S. M. (2014). Creating a critical literacy milieu in a kindergarten classroom. Journal of Language and Literacy Education, 10(1), 45-64. Retrieved from http://jolle.coe.uga.edu

St. James Lutheran. (2017). The importance of story dictation. Retrieved from http://school.stjameslutheran.org/2015/10/06/the-importanceof-story-dictation/

Trilling, B., \& Fadel, C. (2009). $21^{\text {st }}$ Century Skills, Learning for Life in Our Times. San Francisco: Jossey Bass.

Vasquez, V. M. (2014). So the boys won't bother us: Kindergarten students as researchers, Language Arts, 92(1), 52-58.

Wray, D. (2013). Developing critical literacy: A priority for the $21^{\text {st }}$ century. UK: University of Warwick.

Yazan, B. (2015). Three approaches to case study: Yin, Merriam, and Stake. The Qualitative Report, 20(2), 134-152.

Yin, R. K. (2003). Case study research: Design and method (3rd ed.). Thousand Oaks: Sage Publications, Inc.

Yuliariatiningsih, M. S., Ananthia, W., \& Yanthi, N. (2013). The application of picture-mapping method in storytelling to develop young learners' English vocabulary mastery. The International Journal of Teacher Education UPSI-UPI, 1(1), 104-109. 